日消外会誌 $22(4): 1005 \sim 1009 ， 1989$ 年

特集 7

漿膜露出胃癌の腹膜再発防止を目的とした遺伝子組換兄型

interferon $\beta$ 腹腔内投与の試み

\begin{tabular}{|c|c|c|c|c|c|c|}
\hline \multicolumn{7}{|c|}{ 国立病院四国がんセンター・・外科1), 病理2) } \\
\hline 嶋 & 成光 ${ }^{1)}$ & 佐伯 & 英行1) & 多幾山 渉1) & 栗田 & 啓1 \\
\hline & 浩之 ${ }^{1)}$ & 棚田 & 稔1) & 数逸 ${ }^{1)}$ & 大田垣 & 純 ${ }^{1}$ \\
\hline 1 & 正和 ${ }^{1)}$ & 土之 & 義 2$)$ & 昭介 ${ }^{2)}$ & & \\
\hline
\end{tabular}

\title{
A TRIAL OF THE INTRAPERITONEAL ADMINISTRATION OF RECOMBINANT INTERFERON- $\beta$ FOR THE PREVENTION OF THE POSTOPERATIVE PERITONEAL RECURRENCE IN GASTRIC CANCER WITH SEROSAL INVASION
}

\section{Sigemitu TAKASHIMA ${ }^{1)}$, Hideyuki SAEKI ${ }^{1)}$, Wataru TAKIYAMA ${ }^{1 \text {, }}$ Hagime KURITA $^{1)}$ Hiroyuki SOGA ${ }^{1)}$, Minoru TANADA ${ }^{1)}$, Kazuitu ISHIDA ${ }^{1)}$, Jun OOTAGAKI ${ }^{1)}$ Masakazu MURAKAMI ${ }^{1)}$, Hiroyoshi DOIHARA ${ }^{2)}$ and Shosuke MORIWAKI ${ }^{2)}$ \\ Department of Surgery ${ }^{1)}$ and Pathology ${ }^{2}$, Shikoku Cancer Center Hospital}

\footnotetext{
漿膜露出胃癌の腹膜再発防止の目的で Recombinant interferon- $\beta$ (IFN- $\beta$ ) の術後腹腔内投与を試 みた。

胃癌癌性腹水 10 例では著効 2 例，有効 4 例（奏効率 $60 \%$ ）を得た。特に低分化腺癌，印環細胞癌に 強い効果を認めた，発熱以外の重篤な副作用はなく，剖検例の検索で瘜着を促進するような刺激作用 は認めなかった，墏膜露出胃癌13例に対する術後腹腔内投与では，縫合不全，イレウスなどの合併症 は無く治癒手術例では腹膜再発を認めていない。

$\mathrm{S}_{2}$, 肉眼的治癒手術例を対象に IFN- $\beta$ の術後腹腔内投与の有無での比較試験を行っており, 術後補 助療法としての本法の評価を明らかにしたいと考えている.
}

索引用語：胃癌, 腹膜転移, interferon

\section{はじめに}

漿膜露出胃癌に対する腹膜再発防止策は胃癌治療成 績向上のための, 最も重要な課題の一つである，腹膜 再発の成立機序に関する研究とともに文，これに基づ いて各施設で種々の新しい腹膜再発防止の工夫が行わ れているが，いまだ評価の固まった治療法は少ない。

私達はcytokineの 1 種である遺伝子組換方型

* 第32回日消外会総会シンポ 1 ・漿膜露出胃癌治療の 工夫

$<1988$ 年10月12日受理 $>$ 別刷請求先: 高嶋 成光 ₹790 松山市堀/内13 国立病院四国がんセンター 外科
Interferon $\beta$ （協和酸提供, 以下 IFN- $\beta$ ) の癌性腹水 に対する強力な抗腫瘍効果と剖検例での腹腔内痁着防 止作用の観察から, 腹膜露出胃癌の腹膜再発防止に有 効と考え，術後腹腔内投与を試みているので報告する.

1. 癌性腹膜炎に対寸るIFN- $\beta$ 腹腔内投与の効果

進行・再発胃癌10例の癌性腹水に対して IFN $-\beta$ を投 与した。本剤の第II相試験を行った GKT- $\beta$ 研究会の 投与法にしたがい,一回投与量600 1800万単位を腹腔 内留置カテーテルより連日投与した。

効果判定は固形がん化学療法の臨床効果判定基準の がん性体腔液に対する効果判定法によった2．

腹水消失と腹水細胞診の陰性化が 4 週間以上持続し 
た著効が 2 例 $(20 \%)$, 細胞診の陰性化と腹水の減少を 認めた有効が 4 例 (40\%)，奏効率は60.0\%であった。 副作用は軽度の発熱以外は認められず，長期連日投与 が可能であった．細胞診陰性化例は原発巣の組織型が 低分化腺癌および印環細胞癌であり，投与開始より7 日～52日（平均18.9日）で陰性化を確認し，効果持続 期間は，15日２05日（平均76.9日）であった．奏効例 の50\%生存日数96日，無効例41日で，奏効例では生存 期間延長にもつながった（表 1)。

腹水細胞診の所見では腫崵細胞の减少, 変性ととも に, 背景にマクロファージ, リンパ球, 好中球が出現 した，細胞診が陰性化しなかった症例でも，全例腫瘍 細胞の減少と, 変性（胞体の空胞化, 核濃縮など）を 認めた（図 1).

2 . 術後 IFN $-\beta$ 腹腔内投与

肉眼的に漿膜面に癌浸潤の認められる（S2以上） 13 例に対して術後 IFN- $\beta$ 腹腔内投与を行った。治瘾手術 4 例, P因子による非治㾤手術 9 例であり, 術当日 $600 \sim 1800$ 万単位, 術後 1 週目上り600万単位, $7 \sim 20$ 日間留置カテーテルより連日投与した。

発熱が 5 例，白血球減少が 5 例に認められたが，い ずれ軽度で投与中止例はなかった。排ガスは 3 - 6 病 日までにあり，腸閉塞，縫合不全などの術後合併症は 認めなかった。非治瘜手術例の 1 年生存率は $20 \%$ 之期 待した効果は認めなかったが, 治癒手術例では全例再 発なく健在である（表 2).

3 . 剖検例の検討

IFN- $\beta$ 投与例13例に剖検を行った。癌性腹膜炎 8
表 1 胃癌癌性腹膜炎に対する interferon $\beta$ 腹腔内 投与症例

\begin{tabular}{|c|c|c|c|c|c|c|c|c|}
\hline 足琶 & 年合-姓 & 原镉 & 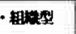 & 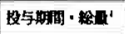 & 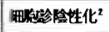 & 䐗水交化 & 奻果半掟 & 生左期周 \\
\hline 1 & $50 \mathrm{~F}$ & 再㠰 & 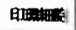 & $1188 \quad 1194$ & $+(205)$ & 消失 & 碚効 & $467 \mathrm{~B}^{2}$ \\
\hline 2 & $69 \mathrm{M}$ & 進行 & 低分化 & $478 \quad 254$ & $+(140)$ & 地少 & 有奻 & $191 \mathrm{~B}^{\prime}$ \\
\hline 3 & $54 \mathrm{M}$ & 進行 & 侮分化 & $448 \quad 246$ & $+(61)$ & 城少 & 放奻 & $97 \mathrm{日}^{3}$ \\
\hline 4 & $53 \mathrm{~F}$ & 再器 & 但分化 & 33 日 $\quad 168$ & $+(52)$ & 竧少 & 有効 & $598^{\circ}$ \\
\hline 5 & $59 \mathrm{~F}$ & 再吪 & 侮分化 & 26 日 144 & $+(33)$ & 城少 & 蛀 & 43 日 $^{\prime}$ \\
\hline 6 & $56 \quad \mathrm{~F}$ & 再発 & 低分化 & 96 日 666 & $+(32)$ & 消先 & 吾奻 & $98 \mathrm{~B}^{\prime}$ \\
\hline 7 & $57 \mathrm{~F}$ & 再発 & 不明 & $\begin{array}{lll}89 & 1428\end{array}$ & $+(15)$ & 不裂 & 策勃 & 1038 \\
\hline 8 & $72 \mathrm{M}$ & 進行 & 不明 & $208 \quad 96$ & - & 不亲 & 筆効 & 22 日 \\
\hline 9 & $38 \mathrm{~F}$ & 再発 & 中分化 & 17日 270 & - & 不妾 & 要就 & $35 \theta^{\prime}$ \\
\hline 10 & $61 \mathrm{~F}$ & 再㚾 & 中分化 & $298 \quad 324$ & - & 不表 & 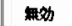 & $75 \theta^{\prime}$ \\
\hline
\end{tabular}

目 1 左：IFN- $\beta$ 投与前. 分泌能を有する低分化腺癌 細胞を多数認める。右：投与 2 週目。畽湯細胞は著 明に减少し背景に好中球, リンバ球, マクロファー ジが多数出現している。

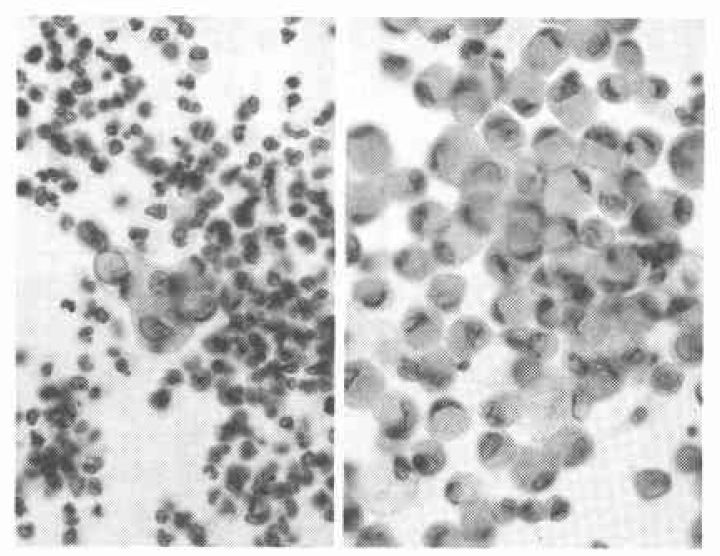

表 2 術後投与症例

\begin{tabular}{|c|c|c|c|c|c|c|c|c|c|}
\hline 症例 & 年令・性 & 肉期分類・紻纉型 & 治流度 & 投与期間・䊅量| & 併用郕 & 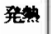 & 白血球站少 & 排ガス日数 & 予媵 \\
\hline 1 & $58 \mathrm{M}$ & 高分化 & 相対佁穜 & $8 \mathrm{~B} \quad 60$ & - & - & - & 58 & 20 月健生 \\
\hline 2 & $62 \mathrm{M}$ & IV 中分化 & 䋦対排治䠣 $\left(\mathrm{P}_{3}\right)$ & 8 日 60 & $5 F U$ & + & - & 3日 & 12 月再死 \\
\hline 3 & $58 \mathrm{~F}$ & 低纷化 & 䎦対非治䆛 $\left(\mathrm{P}_{3}\right)$ & 8 日 60 & $5 F U$ & + & - & 6日 & 9月再死 ${ }^{2}$ \\
\hline 4 & $36 \mathrm{~F}$ & IV 低分化 & 相対诒窎 & 15日 90 & - & - & 2300 & 3日 & 17 月煡生 \\
\hline 5 & $59 \mathrm{M}$ & 低外化 & 䑨対排治灌 $\left(\mathrm{P}_{3}\right)$ & $15 \mathrm{~B} \quad 90$ & ux. 5P & - & - & $3 \mathrm{~B}$ & 7月再死 \\
\hline 6 & $37 \quad F$ & IV 低分化 & 相対非治嵒 $\left(\mathrm{P}_{2}\right)$ & 15 日 90 & $m$ & + & - & 6日 & 8月再死 \\
\hline 7 & $\begin{array}{ll}36 & F \\
\end{array}$ & 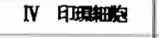 & 䎦対非治愙 $\left(\mathrm{P}_{3}\right)$ & 15 B $\quad 0$ & MC. 5F & - & 1500 & 3 日 & 15 月再生 \\
\hline 8 & $63 \quad \mathrm{~F}$ & 低分化 & 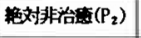 & 8 日 60 & nc. 5ף & + & 2200 & 5日 & 5月再死 ${ }^{2}$ \\
\hline 9 & $\begin{array}{ll}83 & F \\
\end{array}$ & 中分化 & 相対佁裹 & $8 \mathrm{~B} \quad 18$ & - & - & - & 4日 & 14月健生 \\
\hline 10 & $67 \mathrm{M}$ & IV 中分化 & 解対排治昫 $\left(P_{3}\right)$ & 21 日 138 & $5 F$ & - & 2900 & 4 日 & 10 月再死 ${ }^{2}$ \\
\hline 11 & $71 \mathrm{~F}$ & 中分化 & 相対抬垔 & 15日 90 & MC. 5ץU & - & 2500 & 3 日 & 13 月践生 \\
\hline 12 & $39 \mathrm{~F}$ & 低分化 & 绝対非治裹 (P, & $15 \mathrm{~B} \quad 90$ & ux, 5円 & - & - & 5日 & 6月再死 \\
\hline 13 & $63 \mathrm{~F}$ & 低分化 & 相対排治福( $\left(P_{2}\right)$ & $15 \mathrm{~B} \quad 90$ & Mx. 5ケ & - & - & 4 日 & 4月他死 ${ }^{2}$ \\
\hline
\end{tabular}


図 2 剖検時所見：腹膜, 腸管の播種性結節平坦化し て不明瞭となり，腸管壁は平滑で光沢を有し，弾力 性は保たれ，癒着は㾏とんど認めない。

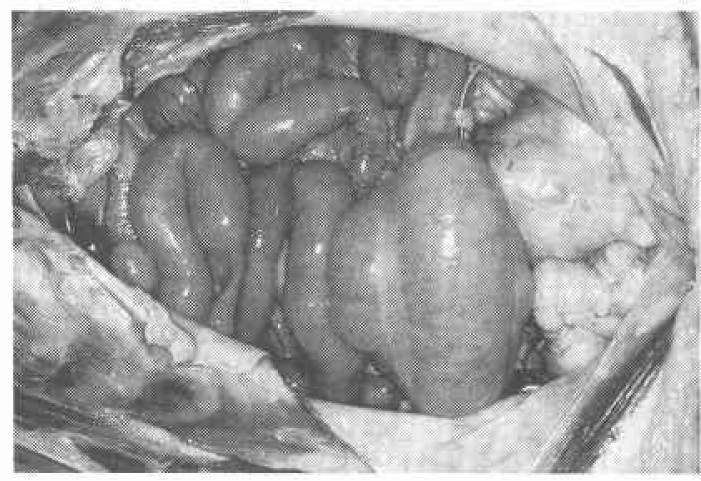

図 3 比較試験投与法

対象：S2, 肉眼的治疼手術例

\section{投与 群}
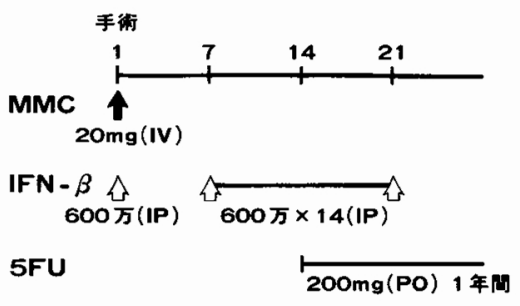

非投与群

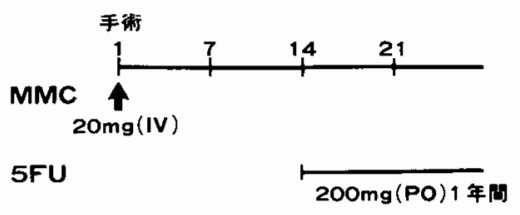

例，術後投与 5 例であり，1例を除き，胃癌の進行， 再発で死亡した。剖検時の腹腔内所見は特異であり， 通常の癌性腹膜炎にみられる腸管扣よび腹膜の播種性 結節は平坦化して不明瞭となり，腸管および腹膜は白 濁肥厚するものの, 光沢を有し, 弾力性は保たれてお り，腹腔内の癒着はきわめて少なかった（図2）.

しかし，顕微鏡的には腹膜，腸管壁内には腫瘍細胞 を認め, IFN- $\beta$ による変性所見に乏しく，6例に認め られた卵巣転移にも効果はみられなかった。

3. 漿膜露出胃癌に対する IFN- $\beta$ 術後腹腔内投与の 有用性の検討

漿膜浸潤胃癌の腹膜再発防止を目的とした IFN- $\beta$
腹腔内投与の有用性を検討するために, randomized controlled trial を実施した。

投一方法は MMC $20 \mathrm{mg}$ 術当日静注, 術後14日より $5-F U ~ 200 \mathrm{mg}$ 経口 1 年間の化学療法に, IFN- $\beta 600$ 万単

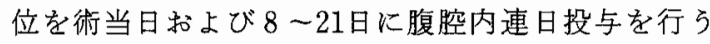
IFN- $\beta$ 投与群と非投与群の比較である（図 3 )。

現在進行中であり，封筒法により各群14例を登録し た。副作用は，投与群で 9 例，非投与群で 7 例に認め られたがいずれも軽度であり投与中止例はない.排が スまでの平均日数は, 投与群 4.1 病日, 非投与群 3.6 病 日と投与群でやや延長しているが, 有意の差ではなく， 臨床的にイレウス症状を認めたものはなかった。

現在までに再発が投与群に 3 例，非投与群に 1 例認 められており, 前者の 1 例は癌死した。投与群の再発 部位は, 肝 2 例, 大動脈周囲リンパ節であり, 腹膜再 発は認めていない。

\section{考察}

胃癌術後再発例の約半数は腹膜再発であり, 特に頻 度の高い漿膜露出胃癌では, 術中の愛護的操作, 徹底 的リンパ節郭清拉よび enbloc 切除などが行われてき たが，これら外科的処置には限界がある。また従来の 術後補助療法でも期待した効果は認められず, 積極的 に腹膜再発防止を目的とした新しい治療の工夫が求め られている。

胃癌腹膜再発の成立機序として, 獎膜面の癌露出部 より脱落した遊離癌細胞が腹膜面に着床, 発育するこ とによるとされている1!

根拠として, 術中腹腔内洗浄細胞診で, 獎膜面露出 胃癌では20〜40\%の高率に癌細胞を証明し，これらは

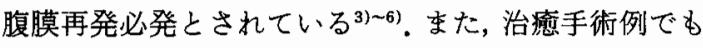
約 $20 \%$ に細胞診陽性であり，これらは潜在性腹膜転移 例と考学られる4).このような病態に対して, 腹腔内に 抗癌剂を投与することは，腹膜再発の機序からも理に 適った方法である。腹腔内への抗癌剤の投与は，癌性 腹膜炎の治療に試みられ，ある程度の効果は認められ ている7) 9)、この結果をふま党て腹膜再発の防止の目 的で術後投与も行われてきたが10)11), 癌性腹膜资に効 果を認めた薬剤であっても，腹膜刺激作用，全身的副 作用などで術後投与には適さないるのが多いこと，厳 密な比較試験での成䋶がないことなどにより，治療法 としての評価は低い，本法は実施が簡単で侵襲も少な い利点がありこれに適した薬剤, 剤型による再検討 が必要と思われる。

Interferonは細胞が産生する生理活性物質一Cyto- 
kine一の 1 種であり，抗ウイルス作用と抗腫湟作用が 注目されている ${ }^{12)}$. Interferonには $\alpha$ 型, $\beta$ 型, $\gamma$ 型 の 3 種があり，これら製剤にはそれぞれ天然型と遺伝 子組換え型がある。後者は天然型と類似した作用を有 し，大量生産が可能なことから，各種腫瘍に対して多 数の臨床治験が行われたが，期待された効果は認めら れていない. 特に多くの期待がかけられた, interferon の宿主の免度担当細胞を介する間接的抗腫笏作用はほ とんど証明されず，悪性黑色腫，脳腫湯などへの局所 投与での直接効果を認めるにとどまっている13114).

腹腔内投与は最も局所親和性の強いIFN- $\beta$ の直接 効果を期待した局所投与の一種である. 全国18施設で の癌性体腔液を対象とした共同研究 (GKT- $\beta$ 研究会) では，1984年 6 月から1987年 3 月委での癌性腹水症例 52 例において $36.5 \%$ の奏効率を認めた．胃癌44例では 著効 15 例 (34.1\%), 有効 2 例 (4.5\%), 奏効率 $38.6 \%$ であった．組織型別で，分化型腺管腺癌 $28.6 \%$ に対し $\tau$, 低分化腺癌 $46.9 \%$, 印環細胞癌 $53.3 \%$ と腹膜再発 を来しやすい後二者に効果が高い特徵を有してい $ろ^{15)}$.

当施設でも，胃癌10例において，著効 2 例 $(20 \%)$, 有効 4 例 $(40 \%)$ ，奏効率 $60 \%$ と顕著な効果を認め，奏 効例はすべて低分化腺癌，印環細胞癌であった，

副作用は軽度の発熱だけであり，長期連日投与が可 能であった，剖検例の検索で，通常の癌性腹膜炎にみ られる，腸管の硬化，癒着による通過障害はほとんぞ 認めず，IFN- $\beta$ には抗腫瘍効果の他に線維化を抑制し て腸管の弾力性を保つ作用を有することが示㖫され た。

継時的に観察した細胞診の所見では, IFN- $\beta$ 特有の ものはなく，他の抗癌凧，免疫賦活剤投与時之類似の 所見であり，腫瘍細胞に対する直接作用が主体と考兄 られる，腹水中で腺塊を形成する分化型腺癌よりる， 孤立傾向のある低分化腺癌，印環細胞癌に効果の高い ことも, 薬剤との接触程度の差による直接効果を反映 したものと思われる ${ }^{16)}$.

術後腹腔内投与に有利な薬剂として, 抗腫瘍効果の 高いこと，局所刺激作用の少ないことの他に，腹腔内 停留が良好で，血中に移行せず，全身性の副作用の少 ないものがあげられる．IFN- $\beta$ は腹腔内投与で血中へ の移行は漂とんど認められず，高濃度に保たれ，連続 投与で蓄積効果のあることが証明されている ${ }^{17)}$. 以上 のことから術後投与も可能と考えた。

安全性確認のため $\mathrm{S}_{2}$ 以上の 13 例飞術後投与を行っ
た。副作用扔よび重篤な合併症は認めず，化学療法と の併用も可能であり，治癒手術の 4 例は全て健在であ り，腹膜再発防止としての術後補助療法の意義を認め た.

比較試験は肉眼的漿膜浸潤陽性（S2）でかつ肉眼的 治瘾手術例を対象とした。治癁手術例でも約 $20 \%$ に認 められるとされている腹腔内遊離癌細胞に対して IFN- $\beta$ の効果を期待したるのである.

一方腹膜転移は遊離癌細胞の着床によるものの他 に, リンパ管を経由するものなど複雑な転移経路が関 与するものと考えられる。これは剖検例の検索で，腹 膜転移とともに晹管壁, 腹膜に高度のリンパ管内腫湟 塞栓を伴うものを認めることや，胃癌取扱い規約では 腹膜転移とみなされている卵巣転移においても，リン パ行性，血行性転移の所見を見るためである ${ }^{18)}$ 。した がって, 腹膜再発防止のためには, 胃癌の進展に応じ た治窟手術に，腹腔内投与と全身化学療法を組み合わ せた補助療法が必要と考穴られ，比較試験の対象症例 を治瘁手術例とし，化学療法を併用したのもこの理由 による，比較試験は現在進行中であり，両群の間に明 らかな差を認めていないが, 腹膜再発防止手段として 最も手軽で，各施設で容易に施行できる腹腔内投与の 再評価の意味でもこの結果を待ちたいと考えている.

\section{文献}

1）古賀成昌：胃癌の腹膜転移の成立機序とその予防 対策。日消外会誌 $17: 1665-1674,1984$

2）小山善之, 斎藤達雄：固形がえ化学療法の臨床効 果判定基準。日癌治療会誌 $21 ： 929-942 ， 1986$

3）大森幸夫, 斎藤 宏, 山宮克己ほか：胃癌患者の腹 腔内にみられる癌細胞について。癌の臨 7： $217-224,1961$

4）中島聰總，及川隆司，大橋一郎法か：進行胃癌に打 ける術中腹腔細胞䛦の嚼床的意義。癌の臨 23 : $27-33,1977$

5）三輪晃一, 山岸 満, 北村秀夫ほか：胃癌手術に扰 ける腹腔内遊離癌細胞の意義。日癌治療会誌 $15: 1131-1136,1980$

6）飯塚保夫，松井孝夫，広岡保明注か：漿膜癌浸潤部 面積から見た胃癌患者の予後。癌の臨 33 ： 273-277, 1987

7）中息聰總，小鍛冶明照，野浪敏明ほか：胃癌の腹膜 播種に対する投与経路別化学療法の比較。癌之化 療 $5: 623-630,1978$

8) Torisu M, Katano M, Kimura $Y$ et al: New approach to management of malignant ascites with a streptoccocal preparation, OK-432. 1. Inprovement of host immunity and prolonga. 
tion of survival. Surgery $93: 357-364,1983$

9）高橋俊雄, 萩原明郎, 伊藤 孝注か：癌性腹膜炎飞 対する抗癌剂の腹势内投与一活性炭吸着制癌剤 (MMC) の腹腔内投与一, 癌と化療 11 : $1550-1556,1984$

10）佐々木廸郎，荻原征美：胃癌に対するマイトマイ シン C (MMC) 術中腹腔内大量洗净療法. その 2 . 臨床成績. 癌と化療 7:1427-1431，1980

11）中島聰總，小鍛治明照，野浪敏明渒か：胃癌の腹膜 播種に対する制癌剂腹腔内投与. 臨外 36 ： 213-219, 1981

12）古江 尚：インターフェロンの投与法と副作用 一生体内動熊からみて一. 癌と化療 11 : 186-193, 1984

13）田口鐵男：各種悪性腫湯患者に対するインター フェロンの效果汅ついて。癌と化療 11 : 194-204, 1984
14）下山正徳：インターフェロンの抗腫痬効果. 日臨 $44: 395-402,1986$

15) 涌井 昭, 斉藤達雄, 中尾 功潘：消化器癌の癌 性腹水に対する Recombinant Interferon- $\beta$ (GKT $\boldsymbol{\beta}$ ) 腹腔内投与の効果. BIOTHERAPY $2: 339-347,1988$

16）高嶋成光, 佐伯俊昭, 佐伯英行ほか: 癌性体腔液に 対する Recombinant interferon- $\beta$ の体空内投与. 癌の臨 $32: 1451-1457,1986$

17) 能塚隆之, 古澤元之助, 友田博次注か：胃癌腹膜再 発に対するインターフェロン一- $\beta$ の腹腔内投与に 関する研究 (IFN の腹水中・血清中濃度と抗腫瘍 効果). 癌と化療 $13: 3538-3540,1986$

18）森脇昭介, 高嶋成光, 北島武志ほか：転移性卵单庫 韵一剖検例と手術例との比較一. 澏の臨 27 ： 343-347, 1981 